\title{
Medical Product Characteristics
}

National Cancer Institute

\section{Source}

National Cancer Institute. Medical Product Characteristics. NCI Thesaurus. Code C53450.

The disting uishing qualities of a medical product. 